\title{
Remembering Guru Nanak: Articulations of Faith and Ethics by Sikh Activists in Post 9/11 America
}

\author{
Sangeeta Kaur Luthra
}

check for

updates

Citation: Kaur Luthra, Sangeeta. 2021. Remembering Guru Nanak: Articulations of Faith and Ethics by Sikh Activists in Post 9/11 America. Religions 12: 113. https://doi.org/ 10.3390/rel12020113

Academic Editor: Knut Axel Jacobsen Received: 28 December 2020

Accepted: 3 February 2021

Published: 10 February 2021

Publisher's Note: MDPI stays neutral with regard to jurisdictional claims in published maps and institutional affiliations.

Copyright: (C) 2021 by the author. Licensee MDPI, Basel, Switzerland. This article is an open access article distributed under the terms and conditions of the Creative Commons Attribution (CC BY) license (https:/ / creativecommons.org/licenses/by/ $4.0 /)$.
Independent Scholar, Los Altos, CA 94024, USA; sluthra66@gmail.com

\begin{abstract}
This paper explores the role of activism as an inflection point for engagement with religious and cultural identity by younger generations of Sikhs in the US. The response of young Sikh activists and the effects on the community are examined in the context of the 11 September 2001 terrorist attacks in the US. The paper begins with the reflections of a Sikh activist about her personal journey learning about Sikh faith and history, and her activism and personal interests. Important themes that reflect the attitudes of contemporary Sikh activists and organizations are discussed. The effects of the post-9/11 backlash against Sikhs in the US are compared to Guru Nanak's experiences of and response to violence, strife, and injustice. The social, psychological, and spiritual benefits of service for those who provide service and care are explored in relation to Sikh philosophy, and from the point of view of contemporary cultural and historical studies of Sikh seva (selfless service) and humanitarianism. The paper concludes that many Sikhs, particularly those coming of age in the late 20th and early 21st century, often referred to as millennial and Generation Z, view social justice activism, humanitarianism and Sikh seva as central and equal to other pillars of Sikhism like worship and devotional practices.
\end{abstract}

Keywords: Sikhism; activism; humanitarianism; ethics; faith; millennials; Gen Z; civil society

\section{Introduction}

The terrorist attacks on the US on 11 September 2001, commonly referred to as 9/11, sent shock waves throughout the US and the world. For Sikh Americans the attacks led to years of backlash against the community leaving many feeling vulnerable and vigilant about the future (Goodstein and Lewin 2001; SALDEF 2019; Sikh Coalition 2009; Sikh Coalition 2019). In response, the Sikh community, primarily led by younger activists, invested in institution-building, community-organizing, humanitarian work, and expanding Sikh participation in American civil and political life (Singh 2008, 2013; Singh 2003, p. 211). In addition, the Sikh practice of seva (selfless service) is often used interchangeably with "humanitarianism" as Sikhs increasingly engage in seva around the world (Murphy 2004; Nippoldt 2018). This paper seeks to explore the significance of Guru Nanak's legacy of seva and social justice efforts for the current generation of Sikh American activists. The first part of the paper discusses the reflections of a Sikh activist on her evolving Sikh spirituality, identity, and commitment to social justice activism. This is followed by a discussion of Guru Nanak's evolving theology within the context of social and political upheaval he witnessed. The dialectic between faith and ethical practice that Guru Nanak articulated becomes the foundation for the development of later Sikh traditions and beliefs, and in particular provides a model for Sikh American activists who tend to be part of the millennial and Generation Z cohorts. Ethical practice for many young Sikhs is viewed as an essential step towards a deeper understanding of and connection with Sikh spiritual practices and faith. In addition, contemporary Sikh activists in the US and in the global Sikh community tend to support a cosmopolitan or globalist vision, which they believe was also Guru Nanak's perspective. Finally, in a discussion of recent ethnographic studies, one on Sikh seva in India and the US (Nippoldt 2018), one on Sikh seva in the diaspora 
(Murphy 2004), and another on Finnish humanitarianism (Malkki 2015), the psychological, social, political, and spiritual benefits described by study participants are explored holistically.

In order to understand the dynamics of Sikh philosophy and ethical traditions over time and space, we can look to "revitalization movements" theory of social and cultural change articulated by American anthropologist, Anthony Wallace (1956). Wallace summarized revitalization in five phases which reflected the movement from "a period of generally satisfactory adaption" to "a period individual stress," "a period of cultural distortion," "a period of revitalization" that included "cultural reformulation," and finally a "new period of generally satisfactory adaptation" (Kehoe 1989, p. 122). These five phases outline a heuristic for understanding how cultures adapt and survive through periods of stress, violence, acculturation and/or cultural genocide. Wallace proposed that while all cultures adapt and change, they often preserve much of their history and defining cultural narratives (Kehoe 1989, pp. 121-22). Furthermore, holism, the principle that all institutions of a community are interdependent, is an important feature of the theory of revitalization. Sikh Americans, responding to post 9/11 backlash, embarked on building new institutions and embraced activism, civil and political engagement, seva and humanitarianism (Murphy 2004, pp. 359-60). Given the retaliatory murder of Balbir Singh Sodhi on 15 September 2001 (Anwar and Jenkins 2018), the bullying of Sikh children (Sidhu and Gohil 2009, pp. 69-74; Verma 2008, p. 39), the mass shooting at the Sikh Temple of Wiscon$\sin$ (Yaccino et al. 2012), numerous hate crimes, and persistent discrimination Sikhs have experienced in the last 20 years (Sikh Coalition 2009, 2019), and the community's response, it is appropriate to characterize this period as one of revitalization for Sikh Americans. In addition to institution building, activism and engagement, the community has also relied on its cultural and historical memory as building blocks for the future.

The discussion below is informed by a growing body of literature on Sikh American activism and my own ongoing ethnographic research on Sikh American institution building. Research methods I have used include interviews with US based Sikh activists and institution builders, reviewing websites, social media, and public scholarship by Sikh organizations, a tabulation of Sikh organizations before and after $9 / 11^{1}$, and fieldwork primarily in California that involved attending conferences and cultural events and visiting gurdwaras (Sikh houses of worship).

\section{Reflections of a Sikh Activist Remembering "Her Guru" (Teacher or Illuminator)}

The current generation of Sikh American activists, a mix of millennials and Generation $Z$, often express their faith and identity first and foremost through ethical practice. These Sikh American activists are not exceptional in that they share this commitment with their non-Sikh cohorts in the US (Case 2014; Parker et al. 2019). While the desire to solve the big social, economic, and planetary problems is a generally shared experience among millennials and Generation Z, their Sikh peers have an additional incentive. Their experience of $9 / 11$ and its violent aftermath, has shaped their perception of activism as an existential requirement. In this section, my main focus is to explore how activism and other forms of service have become important means for exploring faith and identity by young Sikh activists in the US.

From the very beginning of the Sikh faith, founded by Guru Nanak in the 15th century in northwest India, ethical practice was a central tenet of Sikhism. Guru Nanak expresses this tenet in the verse, "Truth is higher than everything, but higher still is truthful living." ${ }^{2}$

1 See Table S1 in the Supplementary Materials.

2 Shri Guru Granth Sahib, p. 62, Line 11.



Sachahau orai sabh ko upar sach āchāār. | | 5 | |

Truth is higher than everything; but higher still is truthful living. | |5 | |

Guru Nanak Dev. 
Traditionally, Sikhs around the world have expressed faith primarily through prayer in the gurdwara (Sikh place of worship) or at home, and through the celebration of the important Sikh holidays like the birth anniversaries of the 10 Sikh gurus, the martyrdom of two Sikh gurus, and other significant milestones like the establishment of the Khalsa (Sikh baptism) tradition. However, millennial and Generation Z Sikh activists view ethical practice to be a central principle of their faith and many see it as equal to traditional forms of worship.

In 2015, a Sikh activist, R Kaur, spoke with me about her faith journey and the principles that guided her personal and professional development (Kaur 2015b). ${ }^{3}$ Kaur's reflection on her own activism and the growing number of Sikh organizations in the US working on social and political issues is helpful for understanding how Sikh activists think about faith, ethics, and identity. When we spoke, R Kaur had graduated from college a few years earlier and had an interest in working in the areas of poverty alleviation and social justice.

While in high school, R Kaur began attending the Sunday school classes at her local gurdwara to learn more about Sikh history, philosophy, and Punjabi, her ancestral language. While her family regularly attended worship in their local gurdwara, Kaur wanted to engage more. Below she describes how her perspective was different from her parents.

My parents didn't force a lot on me, other than go to the gurdwara and "keep your hair and understand who your gurus are and what Babaji (one of many names for God in Sikh tradition) is." I found myself always wanting to know more, so I found myself lobbying my parents to get up an hour earlier and take me to Punjabi school. I started Punjabi school when I was about 14 and really was intrigued by our history. And I think that was the first exposure that I had to a Sikh academic institution, I would say—downstairs in the Hayward gurdwara. (Kaur 2015b)

During college, Kaur became involved with a Sikh organization, Jakara Movement, which focuses on community building and programs for youth and young adults. In order to continue her education in Sikh philosophy and history, she attended conferences, workshops, and camps sponsored by Jakara Movement other Sikh organizations focused on educational programs for diasporic Sikhs. Kaur describes how these programs shaped her.

... Once college started, I learned about the Jakara Movement and then went to the first conference, I think it was 2007 or so. I just fell in love with the organization and the work they were doing. I felt that their viewpoint really spoke to my thirst for understanding the intersection between being an American and a Sikh in the diaspora and because it made our history relevant to all of the social issues I would face. ... And secondly, having a more solid peer group that was really helpful too ... Jakara was the center of my development in terms of my Sikh identity. Other organizations I did have some exposure to, for example, I went to Sidak twice, through Sikh Research Institute, and I found their way of approaching things also very helpful in terms of foundational understanding in terms of Gurmukhi [Punjabi alphabet] and the history aspect, and also Saanjh and Safar. (Kaur 2015b)

After college, Kaur continued to volunteer with the Jakara Movement and to be inspired by the historical examples of the Sikh gurus' activism and by Sikh scripture and philosophy. In particular, she identified with the core principles of humility, compassion, and a belief in the equality of all people. These principles informed Kaur's personal and professional perspectives on contemporary movements for social justice like anti-racism, LGBTQ rights and poverty alleviation work. Visits to India with her family, during which she was deeply moved by the extreme economic and social deprivation and disparities also influenced her desire to ally with marginalized communities. All of these experiences

In 2014, my research was approved by the IRB at Santa Clara University. The IRB approval requires that I follow US government guidelines for consent and confidentiality for human subject research. 
led to what she describes as a deepening of "... my personal faith and my relationship with my guru. I did want to have a mark on the world and I did want to have a positive effect" (Kaur 2015b).

As R Kaur developed relationships with other activists, her parents expressed reservations about her involvement with new Sikh organizations. They worried about the level of her involvement, which they felt was extreme and could not relate to because they had grown up in India and in communities where one learned one's culture and language through immersion. Over time, however, Kaur's parents began to appreciate their daughter's commitment to self-education and to her community of Sikh peers and activists. R Kaur makes the important observation that her generation, growing up in the US were used to questioning the status quo, unlike her parents' generation many of whom had grown up in India where the norm was to privilege the perspectives of elders over youngsters and men over women. She summarizes what she sees as generational differences between young activists and their parents' attitudes.

I think that it goes back to the difference in the way Sikhi is viewed and how Sikhi is used in one's life. I think what we expect from our faith today is often different from another [older] generation. Appearances are not enough. There needs to be a strong personal connection. It can't just be told to you that "this is just how we do things." If there's not a strong personal connection, then Sikhi is just not going to resonate. It is very easy to get away from Sikhi in this environment. It's not like being in India. If we can't make that personal connection with Sikhi then that needs to be facilitated. It's not something that someone can just do himself or herself. That's the role of the sangat [community or congregation] and of these alternative institutions. (Kaur 2015b)

Reflecting on her experience as a woman in the community and changing roles for women in the new Sikh organizations, Kaur describes a process that is at times progressive and substantial, and at other times more symbolic.

In some organizations there's that intentional push to put a woman on the forefront so that they are seen and that we are challenging the way we look at leadership within organizations. One the other side it is somewhat of a quota if at all. A lot of the dialogue that happens is very specific to the male perspective, and the Sikh male identity. There are organizations that are mindful of it and there are organizations that just do what they do to make people happy, but it's not sincere. ... I don't have an exact percentage [for Jakara Movement] but the overwhelming majority of leadership and volunteers in our organization are female and I think that's done intentionally. When we have conferences, we are trying to swing the pendulum to the other side and highlight the female experience. ... I saw how intentional the older people [in the organization] were about setting that tone. I was kind of awestruck with how many strong women there are in our community. It's not that that's changed but it doesn't get highlighted and demonstrated and I think that is really important. (Kaur 2015b)

In other work, I suggest that the new Sikh institutions post-9/11, in particular those focused on civil rights, activism, and community building, have generated more opportunities for Sikh women to take on leadership roles and to be recognized for that work (Luthra 2017). ${ }^{4}$ I believe this represents an important moment for shifting attitudes toward women's roles in the community. However, more research needs to be done to understand whether in the larger community an acceptance of Sikh women leaders will extend to gurdwaras and to what extent it will redress the particular forms of exclusion and subservience expected of many Sikh women and girls in family and community life. Other Sikh activists,

4 See Table S1 in the Supplementary Materials for a listing of Sikh organizations and the participation of women and millenials in these organizations. Acknowledgement: This Table was published with an earlier article in Sikh Formations, 21, June 2018, copyright Taylor \& Francis, available online: http:/ / www.tandfonline.com (accessed on 23 November 2020), doi/full/10.1080/17448727.2018.1485374. 
A Kaur (Kaur 2014) and J Kaur (Kaur 2015a), agree with R Kaur's assessment that the progress being made is important but has not been achieved evenly in all segments of Sikh society.

In April 2015, in recognition of Sexual Assault Awareness Month, the Sikh organization, Jakara Movement, published an "open letter" to address the silence around the issues of sexual abuse and domestic violence within the community (Jakara Movement 2015). R Kaur felt that this was a milestone moment for the organization by shining a light on a difficult issue that has been generally ignored. The response from the Sikh community regarding the open letter was mostly positive. Kaur described how many people shared the letter on their social media platforms, and others sent messages of thanks and approval to the board of the Jakara Movement for breaking the ice on an important and relevant issue and one that reflects the Sikh gurus' respect for women. The Sikh Family Center is another Sikh organization that has raised this issue and runs an anonymous hotline and helps with referrals for domestic violence and abuse victims (Sikh Family Center).

Many in the Sikh community cite Guru Nanak's 16th century verse challenging the pervasive and long-standing belief that women are inferior to men: "So why call her bad? From her kings are born. From woman, woman is born; without woman, there would be no one at all" (Shri Guru Granth Sahib 1604, p. 473, Line 9). While this verse seems to be a clear renunciation of the denigration and second-class status of women, the lived reality for many Sikh women, over the course of more than 500 years, has not led to the realization of Guru Nanak's aspiration (Jakobsh and Nesbitt 2010, pp. 19-22). Jakobsh observes that even the scriptural basis for a Sikh view of the equality of women to men is equivocal at best as is evidenced by verses in which women are depicted as obstacles to moral rectitude and to spiritual salvation (Jakobsh 2003, pp. 25-27). Purnima Dhavan describes the period after the death of Guru Gobind Singh, in which the success of Sikh battles against local Muslim and Hindu rulers led to the establishment of a Sikh landed gentry which led to upwardly mobile caste practices that further restricted the freedoms of women and eventually led to more restrictive roles and purdah for Sikh women (Dhavan 2010, pp. 60-82). Dhavan concludes that, 100 years later in the 19th century, Sikh women continued to face traditional restrictions and subservience to men (Dhavan 2010, pp. 60-82). During the colonial period the practice of female infanticide was widespread in Punjab even in the face of the British campaigns to end such practices (Malhotra 2010, pp. 83-114). In the contemporary period, Sikh girls continue to be devalued starkly as evidenced by high rates of female feticide through sex-selective abortions in North India (Khanna 2009). Nicola Mooney describes the persistence of gender inequality among diasporic Sikhs at the turn of the 21st century. She states that "Jat culture, whether rural and historical or urban, middle-class, and contemporary takes precedence over the gender-egalitarian virtues and values of Sikhi" (Mooney 2010, p. 180). The question of gender parity in Sikh scripture is a complex one and much of Sikh society still sees girls and women as lesser than their male counterparts. However, there are small improvements, as I have suggested above. Post 9/11 activism in the US seems to be generating opportunities for Sikh women to assert their influence and to be accepted in leadership roles in their communities, and I believe these opportunities may positively impact women's experiences in other areas of Sikh life (Luthra 2017).

In acknowledging socioeconomic disparities in the Sikh community, R Kaur talked about the Sikh community often presenting itself as a model minority, and her ambivalence about this representation (Kaur 2015b). She explains her discomfort with this characterization which implies that, "a model citizen ... is one having an affluent job, contributing to society, having a 'full' family with both boys and girls" (Kaur 2015b). Kaur feels that the presumption of economic success and traditional family life leaves many Sikhs feeling marginalized and unaccepted because they may not have an affluent lifestyle or they may not have a conventional family life. For Sikhs who are working class, single, or married but without children, or identify as LGBTQ, trying to conform to model minority standards can be alienating. 
Unease with the "model minority" mantle has been expressed by Judge and Brar in their essay, "Guru Nanak is not at the White House: An essay on the idea of SikhAmerican redemption" (Judge and Brar 2017). Judge and Brar reject common refrain used by some Sikh organizations that "Sikh values are American values." They argue that the equating of Sikh values with American values is a distortion of the core principles and philosophy of the Sikh gurus; and an erasure of the original American sins, the genocide and displacement of indigenous peoples, a long and brutal legacy of slavery and continuing systematic exploitation of black and brown people (Judge and Brar 2017, pp. 147-48).

Another dilemma that the "model minority" and "Sikh American" appellations generate, especially in light of the post-9/11 backlash, is a false choice between "model minority" and "victim." In his paper, "Precarious and model minority: Sikh identities in the "new" global politics of religion," Pal Ahluwalia explores this dilemma for Sikhs not only in the US but in the UK and globally (Ahluwalia 2019).

In many parts of the world, Sikhs have come to be perceived as a "model" minority—so much so that some have critiqued the Sikh community for taking up positions that are perceived as assimilationist. Such critiques, however, gloss over the sense of precarity, and the litany of hardships, racial discrimination and legal battles in which Sikhs have been forced to be engaged in a post-9/11 world. ... Hence, conceptualizing Sikh identities as precarious, vulnerable "model minorities" in a post-Brexit/Trump era allows us to explore a Sikh ethics underpinned by the universal message of SGGS Ji. This is so because such ethics have never been conceptualized as simply being "other-worldly," but rather as precisely grounded in the world that has been entrusted to us. (Ahluwalia 2019, p. 332)

Ahluwalia's analysis highlights how Sikhs around the world, and I would suggest particularly in the US, have responded to discrimination and hate crimes through political engagement and activism, allowing them to reconcile these contemporary yet contradictory realities. As mentioned above, since $9 / 11$ Sikhs in the US have experienced a persistent and dangerous backlash expressed through workplace discrimination, racial profiling in airports and other government buildings, bullying of Sikh children in schools, and numerous hate crimes against Sikh persons and property and against community gurdwaras (Sidhu and Gohil 2009, pp. 59-103; Sikh Coalition 2014). Just days after the 9/11 attacks, the backlash resulted in the murder of Balbir Singh Sodhi in in front of his business in Mesa, Arizona. The backlash continued unabated for years, culminating in a mass shooting at the Sikh gurdwara in Oak Creek, Wisconsin in 2012 (Singh 2013). Ultimately, seven people including the shooter died, and three were injured. That the shooter, Wade Michael Page, identified as a white supremacist made the attack even more sinister and troubling to a community that had lived in relative harmony with their non-Sikh neighbors (Michaelis and Kaleka 2018).

The dark reality of the post-9/11 backlash led many Sikhs to identify as victims, an image that was at times difficult to reconcile with the image of a model minority embraced by many in the community. In the years following, Sikh activists, organizations, gurdwaras, and citizens spent a great deal of time and money defending themselves against prejudice and threats of violence (Jakobsh 2017; Luthra 2017; Singh 2008; Verma 2008). One common response was to engage in outreach and education about Sikh history and culture directed at the general public, local and national governments, law enforcement, and the media (Murphy 2004, pp. 358-60). However, the Sikh ethos of Chardi Kala (rising optimism) has been referenced by Sikhs as they reconcile their resilience with their victimization. Out of this very difficult time, a new image of the community has emerged. Today Sikh communities and institutions are being recognized in the US and around the world for their seva, humanitarian work, and for their commitment to fighting for social justice for all people (Murphy 2004, pp. 348-57). Recently the organizations United Sikhs and 
Khalsa Aid USA are examples of growing momentum and support for the area of Sikh humanitarianism (Krishna 2020; Lee 2020). ${ }^{5}$

While Sikh civil society in the US continues to expand and become more representative of the diverse needs and priorities within the community, there are still limitations and challenges for Sikh organizations and communities. R Kaur spoke, for example, of the need for more collaboration between Sikh organizations and for better coordination and communication with gurdwaras around the country. She describes the kinds of challenges she and some of her peers have observed:

Well, it depends, on the type of community or what area it is. Those who haven't seen organizations like Jakara might be really welcoming, while others have a kind of burn out and they see this [outside organizations] all the time and they think it's just another group.... When we talk about other Sikh organizations that are not gurdwara focused, I think there is a lot of mutual desire for collaboration, and we have had those types of events happening more in recent years. I think that as the organizations grow what's going to matter is whether you stay aligned with the core of our beliefs and Sikhi. But that will always come back to the gurdwara because that is the central place where our community does gather. And the goal is to serve the community. I see it as an ecosystem that will feed each other. Right now, I do see an imbalance. (Kaur 2015b)

\section{Contextualizing R Kaur's Personal and Activist Journey}

$R$ Kaur's interview explores a number of themes that reflect the ethos of many contemporary Sikh activists in the US. The first theme is a spiritual coming of age narrative that explores what it means to identify as a Sikh in the diaspora. As Kaur states above, "it's not like being in India, you have to make an effort to learn [Sikh history and philosophy]" (Kaur 2015b). Another theme is the desire to integrate faith and worship with a call to action for social justice and to continue the legacy of the Sikh gurus. Kaur describes being drawn to the Jakara Movement's awareness of Sikh history and traditional organizational models like misls (chapters) to support the needs of the communities they serve. ${ }^{6}$ Kaur and her cohort of Sikh activists see their work as remembering their history and the Gurus institutions as they design and build their own community-based programs and nurture alliances with activists of diverse backgrounds in the US. Fighting for equality, for Sikhs and non-Sikhs alike, is both a strategic and moral decision.

$\mathrm{R}$ Kaur's narrative also offers a window into how many diasporic Sikhs learn and connect with Gurbani (the Guru's words) and the Guru Granth Sahib, the primary Sikh scripture viewed as a living Guru. This learning occurs in various settings like Khalsa/Punjabi school programs offered by many community gurdwaras. These schools offer classes in Gurmukhi (the Punjabi alphabet), Punjabi language, and Sikh history. Other ways of learning about Sikh beliefs include participating in seva both in the gurdwara and in the wider non-Sikh community; attending Sikh camps and conferences; online forums and websites dedicated to Sikh history, philosophy, language, and sociocultural issues; and finally, for many like R Kaur, visits to India and to directly experience Sikh history and culture. Each of these contexts elicits a distinct mode of learning-liturgical, participatory, and experiential. In addition, the overlaying of context, content, and experience generates an intuitive and holistic understanding and a visceral or emotional experience of Sikhi (Sikhism) as philosophy, faith, ethics, and culture. In her reflection above, Kaur is particularly passionate about the need to nurture a "personal connection to Sikhi," without which she feels diasporic Sikhs will "get away from Sikhi" (Kaur 2015b). Kaur values the integration of faith, ethics, and activism within Sikh organizations, and emphasizes how

5 For more information on the work of United Sikhs see https:/ / unitedsikhs.org/ (accessed on 23 November 2020) and for Khalsa Aid USA, see https:/ / www.khalsaaid.org/ donate-usa (accessed on 23 November 2020).

6 https://m.facebook.com/jakaramovement/posts/10154744457573990:0 (accessed on 23 November 2020). 
important her experiences with Jakara Movement and activism in general were in shaping "my personal faith and my relationship with my Guru" (Kaur 2015b).

$\mathrm{R}$ Kaur and other Sikh activists, working for civil rights, community building, and various other social justice causes, see themselves as "connecting" with what they see as Guru Nanak's original project. They see their work as coming from the heart of Sikhism, what GS Sahota describes as Guru Nanak's "rational civil theology" (Sahota 2011). Citing J.P.S. Uberoi, Sahota points to the egalitarian ideal within Guru Nanak's vision:

For Uberoi, Sikhism "set out to annihilate the categorical partitions, intellectual, and social, of the 'medieval world' by rejecting 'the opposition of the common citizen or householder versus the renouncer, and of the ruler versus these two, refusing to acknowledge them as separate and distinct modes of existence." (Sahota 2011, p. 135)

Guru Nanak's ethos challenges the status quo in order to articulate a theology based on the truth of the oneness of existence; and the "annihilation" of religious orthodoxy described above, is driven by the need to make room for something new, what Sahota describes as " ... the coordinates of an ethics based in reason, virtue, justice, civility, truthful relations with the other as the one and the whole" (Sahota 2011, p. 136). Sahota goes on to elaborate how intertwined Guru Nanak's spiritual awakening was with his worldly practices:

For Guru Nanak, the illusion of a fundamental separation between the self and the other, between the subject and the object, had to be dispelled in experience and through practice, and not merely in thought. The focus was on cultivating collective norms and inculcating a mindfulness of the whole. (Sahota 2011, p. 138)... It is perhaps no surprise then to see that the daily routines in the commune Guru Nanak established in Kartarpur in 1526 emphasized in their totality a negation of this core illusion of civil society. Collective sociality rather individuality is expressed at every level, suggesting that the ultimate negation of the source of evil—ego—can only be the actualization of practices that fundamentally undo it. (Sahota 2011, p. 139, emphasis added)

While the popular imagery of Guru Nanak is that of the wandering sage, Sahota highlights the Guru as an activist critically engaged with the dominant religious and socioeconomic institutions of his time. The Guru's commitment to standing up to injustices especially when perpetuated by the powerful against the powerless is shown to be central to his mission and was furthered by his efforts to build alternative social and ethical practices. The characterization of Guru Nanak's theology as rooted in "rational" and "civil" is attractive for many young Sikhs for whom projecting a modern and progressive image with which they can relate and is also particularly useful in the diaspora. Grewal in a paper on Sikh women asylees in the US also notes the desire of Sikh leaders to project an image of Sikhs as modern (Grewal 2010, p. 290). Sikhs in the diaspora for whom the experience of feeling like a perpetual outsider act pragmatically to appeal to the values of their adopted homes. Dusenbery describes the need of diasporic groups to curate their image and behavior in order to feel comfortable and accepted:

... Sikhs in all locales have had to come to terms with what it means to be a Sikh at large in the face of alternate and changing modernities. In fact, many of my more thoughtful and articulate Sikh friends and informants over the years have been well aware of being engaged in a process of making Sikh subjects who can thrive in new and varied social settings without ceasing to be Sikhs. (Dusenbery 2008, p. 5)

There are however some real historical parallels between Sikh activists of the millennial and Generation $\mathrm{Z}$ cohorts and similar experiences and motivations of Guru Nanak and the early Sikhs. Both were deeply concerned with injustice and inequities in their respective societies. Both are also increasingly embraced a universal and humanitarian worldview that challenged parochial divisions. As R Kaur's reflections above suggest, many Sikh 
activists aspire to these ideals and seek to apply them in their work as institution builders, and in their personal faith journeys.

Pashaura Singh explores a different but equally formative experience in Guru Nanak's life, that of Babur's invasions of Punjab in 1526 (Singh 2020). In his paper "Speaking Truth to Power: Exploring Guru Nanak's Babur-Vani in Light of Baburnama," Singh says that Guru Nanak understood the need for both spiritual-political praxis $(2020$, p. 12). Shaken by the violence he witnessed, Guru Nanak lamented the cruelty and destruction unfolding around him (Singh 2020, p. 16). In another vein, Nikky-Guninder Kaur Singh describes the impact of Babur's invasion on Guru Nanak's understanding of the effect on Punjab's women, in particular.

Baburvani questions patriarchal institutions. The historical attack heightens Guru Nanak's consciousness, and practices like purdah and sati along with the convictions that undergird them, force themselves upon his attention. (Singh 2016, p. 17)

Equally important was the effect on the early Sikh community at Kartarpur, which led to the establishment of new social spaces and practices that could undo the prevailing religious and social conventions and plant the seeds for a realization of unity at the center of Sikh theology. After the violence unleashed by Babur, according to Pashaura Singh, Kartarpur became even more important as a model for a devotional and loving community (Singh 2020, p. 16). Equally significant was that Kartarpur was the site of the first Guru Ka Langar (community kitchen) in which the hierarchies of wealth, caste, and gender were discarded, and in which all, regardless of sect or religion, were welcome. The institution of Guru Ka Langar was significant in that it rejected the prevailing concepts of ritual pollution and purity which required the strict segregation of low caste from high caste and women from men. However, as Jakobsh observes, the progress was not complete because Guru Nanak's critique of the social order was primarily focused on spiritual equality and not social equality which was evidenced by the persistence of second-class status for women in society (Jakobsh 2003, pp. 25-26). What began with the first Guru continued to develop and it was during the tenure of the Guru Amar Das, "that both scriptural and popular sources attribute a shift towards the inclusion of women in the Sikh panth" (Jakobsh 2003, p. 29). That successor Gurus continued reforms, reflects an "openness" in early Sikh society:

Early Sikhism was not a fully formed doctrine or fixed articles of faith so much as an openness to the course of historical movement itself, to the natural evolution of democratic customs, and the continuous reconceptualization of the mind and the spirit according to the circumstances at hand and ... illuminated by providential wisdom. (Sahota 2011, p. 136, emphasis added)

What the scholarship above tells us about Guru Nanak-his experiences and analysis of historical events and their impact on society—has important significance for many Sikhs today, and in particular with those in the US. As in Guru Nanak's experience of Babur's invasion, the most recent wave of Sikh American activism was also spurred by an apocalyptic moment. The 9/11 attacks left all Americans including Sikhs feeling dazed and confused by the fury of that day. For Sikhs, and other minorities, the attacks were just the beginning of an era of more fury and violence that spurred a call to action and a revitalization movement for the Sikh community. Ultimately R Kaur's reflection illustrates that her identification with "her Guru" is simultaneously personal and collective.

Contemporary Sikh American activists like R Kaur find succor in remembering Guru Nanak's life. The memory of the Guru is forged not only through historical sources, but also in attending classes in gurdwaras, participating in community traditions, and studying Sikh scripture. Equally important but at times not fully articulated, are the bicultural experiences of growing up as a Sikh in America: celebrating American holidays, studying American history, and participating in rites of passage and rites of solidarity like graduations, proms, concerts, and sporting events. 


\section{Seva (Selfless Service) in Contemporary Sikh Culture and Identity}

The traditions of Kartarpur-humility, humanism, equity, and seva-have been revitalized, as many Sikhs around the world are embracing these principles with renewed vigor. In her review of various types of seva, Murphy identifies the following types of seva: Kar seva which has primarily been the work of building and maintaining sacred sites; traditional Langar seva or the community kitchens which are a feature of all Sikh gurdwaras; philanthropy as seva that provides charitable services for those in need; and finally, a renewed interest in activism as seva (Murphy 2004, pp. 348-36). With regard to the latter, Murphy describes Sikh diasporic seva at the turn of the 21st century as redefining the meaning of "the political":

Seva as both concept and action therefore takes complex and inter-related forms. Its relationship to political action is similarly complex ... many of those interviewed for this article emphasized the apolitical nature of their work, as an alternative to militant political action aimed at the establishment of a sovereign and independent state [Khalistan\} ... (Murphy 2004, p. 362)

It is important to note that there have been some differences between the work of Sikh humanitarian organizations and Sikh philanthropists. According to Dusenbery, Sikh philanthropy has primarily been driven by wealthy Sikhs living in the diaspora with the goals of promoting modernization and development in their native Punjab, and often by giving directly to their natal villages (Dusenbery 2008, pp. 150-54). Dusenbery also notes the contribution of diasporic philanthropy to supporting a budding civil society sector in the state (Dusenbery 2008, p. 155). Finally, Sikhs engaging in seva in the 21st century are increasingly articulating a cosmopolitan point of view and often see seva as humanitarian work. The difference between the views of seva as humanitarianism and Sikh philanthropy has been that the latter tended to focus on Punjab and the Sikh community, while the former seeks to "Recognize the Human Race as One" (the slogan of the organization, United Sikhs). Finally, Murphy emphasizes that all of these expressions of seva, modern and traditional, are predicated on the principle of "niskham-done without benefit to the one performing the act" (Murphy 2004, p. 344). The nishkam principle does in fact have one benefit for the sevadar, that is the experience of what Sahota describes as "the ultimate negation of the source of evil-ego" (Sahota 2011, p. 139).

In a 2018 paper, "Transformed through Seva: Personal and Community Experiences of the Sikh Service," Lauren Nippoldt explores, through her ethnographic fieldwork in India and the US, the meaning and impact of seva on Sikh sevadars.

By engaging in seva for the marginalized and for the communities who have harmed their own in the past, Sikhs may be able to shed experiences of trauma and conflict. In this transformative shedding through the practice of seva, a newly healed subject comes into being. The social bonds and new relationships that arise through acts of care and service also foster intercommunity harmony between Sikh sevadars and the communities they serve. (9)

Nippoldt notes that, while seva has been part of other religious traditions in India, in the Sikh faith it is "an essential part of religious life" (Nippoldt 2018, p. 1). She notes evolutionary models of care practices often described as "prosocial behaviors" that have been present since the earliest human societies and are seen as central to the evolutionary success of humans as a species. In general, among humans, prosocial behaviors primarily involve members of "in-groups" (Nippoldt 2018, p. 2). However, the Sikh tradition of seva more often than not involves inter-community service, that in addition to providing care also seeks to subvert social taboos like crossing the "boundaries of caste, class, ethnicity, and religion" (Nippoldt 2018, p. 2). This distinction suggests that the inter-community nature of Sikh seva often goes beyond being a care practice to being much more including a form of humanitarianism, activism, and resistance of the subjugation of subaltern groups.

Another important finding in Nippoldt's research is that there are multiple benefits for sevadars (practitioners of seva) as individuals and as a community. These benefits 
described to Nippoldt by her interlocutors include a sense of peace and fulfillment, a sense of religious duty, a way to find satisfaction outside of consumer culture, a renewed pride in one's Sikh identity, and the perception of a renewed respect for the Sikh community overall.

The idea that seva acts as an antidote to the consumerist lifestyle is particularly interesting because it reflects Guru Nanak's critique of the preoccupation with money and wealth in the "early modern mercantile society" in which he was born (Sahota 2011, p. 132). It is also important to note that the Sikh practice of seva or "selfless service" is ideally offered in a calm and humble manner, or as a prayer. Seva also embodies the Sikh exhortation to value all humans and all of creation, as expressed in the last verse of the Sikh daily prayer, the Ardas: "Nanak Naam Chardi Kala, Tere Bhane Sarbat Ka Bhalla", which translates as "Oh Nanak, in the Name [of the Divine] one finds uplifting optimism, and with the Divine's will all of creation may flourish." ${ }^{7}$

In spite of the perceived benefits of seva, Nippoldt's interlocutors also describe the critique and disapproval they sometimes face from family and friends who see the work as low-status and even potentially dangerous. Finally, Nippoldt notes that there is a generational difference between millennials and Generation Z Sikhs who engage in seva compared to their elders. One difference is that the younger generations often engage in seva outside of the traditional gurdwara programs and settings. Another is their focus and commitment to addressing the needs of marginalized groups and promoting social justice in the wider society. These findings support a holistic view of seva within Sikh tradition and practice. Nippoldt's research suggests her interlocutors view Sikh seva as akin to humanitarianism because both traditions ultimately share the ideal of serving all of humanity without prejudice.

\section{Humanitarianism from a Holistic Perspective}

In her book, The Need to Help: The Domestic Arts of International Humanitarianism, Liisa Malkki explores the positive effects and benefits of humanitarian service on those who give aid and provide care. Based on ethnographic research with Finnish humanitarian professionals and volunteers, Malkki finds that many professionals and volunteers feel their humanitarian work generates a feeling of being more connected to the "world outside," an effect she describes as "relations of self to self" (Malkki 2015, p. 3). Her interlocutors describe social and emotional isolation, which is particularly acute among many elderly people in Finland, as a motivating factor for participating in humanitarian work that offers a "human connection (even if precarious) and helps them to feel like real persons" (Malkki 2015, p. 4).

Malkki seeks to recalibrate the archetype of the heroic aid worker as having both, "impressive strength and good sense, but also for many an undeniable neediness" (Malkki 2015, pp. 2-3). These humanitarians often reap benefits from their work, and although internationalists in intent, they bring with them unique personal histories and situated cultural lenses.

The case I studied, at least, suggests that it is not as generic "global citizens", "worldly nomads", or "cosmopolitans" but as specific social persons with homegrown needs, vulnerabilities, desires, and multiple professional responsibilities that people sought to be part of the something greater than themselves, to help, to be actors in the lively world... This sense of the domestic sheds light on how the conduct of the aid workers "out there" reflects their specific culture regions and social contexts-and the way that aid work abroad presents for some a line of escape from the familiar, and sparks urges to self-transformation. (Malkki 2015, p. 4)

7 I want to acknowledge Ms. Jessi Kaur of Cupertino, CA for helping me with this translation. 
As suggested above, a re-examination of social context and the "needs" and "desires" produced therein, should be applied to understanding Sikh American activism and seva. At the beginning of this paper, I alluded to the events of $9 / 11$ and the violent and prolonged backlash that followed were critical in spurring Sikh American activism and humanitarianism. It is difficult to know if young Sikhs would have been as engaged in civil and political society if $9 / 11$ had not happened. But studies of millennial generation attitudes in the US suggest that they generally are more engaged in activism than older generations (Case 2014; Parker et al. 2019). As Nippoldt's study shows, renewed engagement with seva by Sikhs in India was driven by multiple factors, and therefore it is possible that the same commitment to activism and seva could have developed in the US even without the trauma of $9 / 11$. One thing is fairly certain that Sikhs today are more interconnected through the digital technologies than ever before and this has led to sharing of experiences and values that are no longer limited by physical distance. At the same time, the forms of civil and political engagement by Sikhs will necessarily continue to be shaped by the specific social and political systems in which they are living (Dusenbery 2008, p. 5). Given the longevity of seva stretching back more than 500 years to the time of the first Guru, it is safe to say that the Sikh imperative to serve humanity will continue to be practiced and to remain the foundation of Sikh identity and spirituality.

Finally, Malkki offers a definition of ethics that is dynamic and multidimensional, "ethics can be thought of as an imaginative practice and imagination as an ethical practice" (Malkki 2015, p. 14). It is precisely this interplay of imagination and ethics that reflects what Sikh activists like R Kaur are hoping to achieve- that is, the rebuilding of an ethical practice and an inclusive community by revitalizing Guru Nanak's experiment in Kartarpur within the contemporary realities of globalization and in relation to the diversity and multiculturalism that diasporic Sikhs inhabit.

\section{Conclusions}

This paper makes the case that contemporary Sikh American activists find meaning and motivation through the ethical practices and social justice traditions embraced by Guru Nanak and carried on by his successor Gurus, while also revitalizing that vision to reflect the needs of their time. This generation, coming of age at the turn of the 21st century, is increasingly expressing their faith through activism ..., civic and political engagement, and seva and humanitarian work. In the crucible of $9 / 11$, they have mobilized to establish a new generation of Sikh organizations, and to expand civil society participation (Luthra 2018). In everyday acts, like serving meals to those in need, organizing for civil rights, lobbying governments, marching and speaking out against bigotry and hate, and working to build a more just and equitable society, they seek an alchemy of imagination and ethical practice at the heart of Guru Nanak's faith.

Supplementary Materials: The following are available online at https:/ /www.mdpi.com/2077-144 $4 / 12 / 2 / 113 /$ s1.

Funding: Faculty Student Research Assistant Program, Project ID: FSRP0111, Santa Clara University, 2015.

Institutional Review Board Statement: Approval for Research with Human Subjects, Application 14-01-454, SCU FWA: 00002737, Santa Clara University, 18 September 2014.

Informed Consent Statement: Informed consent was obtained from all subjects involved in the study. The full name of participants will not be disclosed as per signed confidentiality statements.

Data Availability Statement: A full transcript of interviews cited in this paper are available. Contact the author at sluthra66@gmail.com.

Conflicts of Interest: The author declares no conflict of interest. 


\section{References}

Ahluwalia, Pal. 2019. Precarious and model minorities: Sikh identities in the 'new' global politics of religion. Sikh Formations 15: 332-42. [CrossRef]

Anwar, Liyna, and Cameron Jenkins. 2018. 'People Saw Only a Turban and a Beard': Reflecting on a Post-Sept. 11 Death. Available online: https: / / www.npr.org/2018/09/14/647426417/ people-saw-only-a-turban-and-a-beard-reflecting-on-a-post-sept-11 -death (accessed on 20 January 2021).

Case, Jean. 2014. The Business of Doing Good: How Millennials Are Changing the Corporate Sector. Forbes Magazine. Available online: https:/ / www.forbes.com/sites/jeancase/2014/06/18/millennials2014/?sh=39da79e04c34 (accessed on 26 January 2021).

Dhavan, Purnima. 2010. Tracing Gender in the Texts and Practices of the Early Khalsa. In Sikhism and Women: History, Texts, and Experience. Edited by Doris R. Jakobsh. Delhi: OUP, pp. 60-82.

Dusenbery, Verne A. 2008. Sikhs at Large: Religion, Culture, and Politics in Global Perspective. Delhi: OUP.

Goodstein, Laurie, and Tamar Lewin. 2001. A Nation Challenged: Violence and Harrasment; Victims of Mistaken Identity, Sikhs Pay a Price for Turbans. Available online: https://www.nytimes.com/2001/09/19/us/nation-challenged-violence-harassmentvictims-mistaken-identity-sikhs-pay-price.html?searchResultPosition=1 (accessed on 18 January 2021).

Grewal, Inderpal. 2010. Making Sikh Women Refugees in 1990's USA. In Sikhism and Women: History, Texts, and Experience. Edited by Doris R. Jakobsh. New Delhi: University of Oxford Press, pp. 276-98.

Jakara Movement. 2015. An Open Letter to the Sikh Community. Available online: https://www.jakara.org/openletter (accessed on 15 November 2020).

Jakobsh, Doris R. 2003. Relocating Gender in Sikh History: Transformation, Meaning and Identity. New Delhi: Oxford University Press.

Jakobsh, Doris. 2017. Tragic Violence, Hate Crimes and Grieving Within Sacred Geographies of Faith: Sikhs and the Oak Creek Gurdwara Shootings, 2012. Journal of Religion and Culture. 27: 103-31.

Jakobsh, Doris R., and Eleanor Nesbitt. 2010. Sikhs and Women: Contextualizing the Issues. In Sikhism and Women: History, Texts, and Experience. Edited by Doris R. Jakobsh. New Delhi: University of Oxford Press, pp. 19-22.

Judge, Rajbir Singh, and Jasdeep Singh Brar. 2017. Guru Nanak is not at the White House: An essay on the idea of Sikh-American redemption. Sikh Formations 13: 147-61. [CrossRef]

Kaur, A. 2014. Fremont, CA, USA. Personal communication.

Kaur, J. 2015a. Palo Alto, CA, USA. Personal communication.

Kaur, R. 2015b. Los Altos, CA, USA. Personal communication.

Kehoe, Alice Beck. 1989. The Ghost Dance: Ethnohistory and Revitalization. New York: Holt, Rinehart \& Winston, Inc.

Khanna, Sunil K. 2009. Fetal/Fatal Knowledge: New Reproductive Technologies and Family-Building Strategies in India. Belmont: Wadsworth.

Krishna, Priya. 2020. How to Feed Crowds in a Protest or Pandemic? The Sikhs Know. Available online: https://www.nytimes.com/ 2020/06/08/dining/free-food-sikh-gundwara-langar.html (accessed on 23 November 2020).

Lee, Emmanuel. 2020. United Sikhs Help Fire Evacuees. San Jose Inside. Available online: https:/ /www.sanjoseinside.com/news/ united-sikhs-help-fire-evacuees/ (accessed on 22 November 2020).

Luthra, Sangeeta K. 2017. Out of the ashes: Sikh American institution building and the promise of equality for Sikh women. Sikh Formations: Religion, Culture, Theory 13: 308-32. [CrossRef]

Luthra, Sangeeta. 2018. Sikh American millennials at work: Institution building, activism, and a renaissance of cultural expression. Sikh Formations: Religion, Culture, Theory 14: 280-99. [CrossRef]

Malhotra, Anshu. 2010. Shameful Continuities: The Practice of Female Infanticide in Colonial Punjab. In Sikhism and Women: History, Texts, and Experience. Edited by Doris R. Jakobsh. New Delhi: University of Oxford Press, pp. 83-114.

Malkki, Liisa. 2015. The Need to Help: The Domestic Arts of International Humanitarianism. Durham: Duke University Press.

Michaelis, Arno, and Pardeep Singh Kaleka. 2018. The Gift of Our Wounds: A Sikh and a Former White Supremacist Find Forgiveness after Hate. New York: St. Martin's Press.

Mooney, Nicola. 2010. Lowly Shoes on Lowly Feet: Some Jat Sikh Women's Views on Gender and Equality. In Sikhism and Women: History, Texts, and Experience. Edited by Doris R. Jakobsh. New Delhi: University of Oxford Press, pp. 156-86.

Murphy, Anne. 2004. Mobilising seva ("Service"): Modes of Sikh Diasporic Action. In South Asians in the Diaspora. Edited by Knut Axel Jacobsen and Pratap Kumar. Leiden: Brill, pp. 337-72. [CrossRef]

Nippoldt, Lauren. 2018. Transformed through Seva: Personal and Community Experiences of Sikh Service. Paper presented at Sikholars Conference, Stanford, CA, USA, February 17.

Parker, Kim, Nikki Graf, and Ruth Iglieknik. 2019. Generation Z Looks a Lot like Millennials on Key Social and Political Issues: Among Republicans, Gen Z Stands Out in Views on Race, Climate and the Role of Government. Pew Research. Available online: https:/ / www.pewsocialtrends.org/2019/01/17/generation-z-looks-a-lot-like-millennials-on-key-social-and-political-issues / (accessed on 21 December 2020).

Sahota, G. S. 2011. Guru Nanak and Rational Civil Theology. Sikh Formations: Religion, Culture, Theory 7: 131-43. [CrossRef]

SALDEF. 2019. Hate Crimes TRIPLE against Sikhs in the U.S. Available online: https://saldef.org/hate-crimes-triple-against-sikhs-inthe-u-s/ (accessed on 20 January 2021).

Shri Guru Granth Sahib. 1604. Available online: www.srigranth.org (accessed on 15 November 2020).

Sidhu, Davinder S., and Neha Singh Gohil. 2009. Civil Rights in Wartime: The Post-9/11 Sikh Experience. New York: Ashgate Publishing. 
Sikh Coalition. 2009. Fact Sheet on Post 9/11 Discrimination and Violence against Sikh Americans. Available online: http://www. sikhcoalition.org/images/documents/post_9.11_fact_sheet_revised.pdf (accessed on 20 January 2021).

Sikh Coalition. 2014. [AVAAZ] Interfaith Greeting, “Connecting with 1984” Small Grants Pool, Anti-Bullying Congress Letter and More! Available online: https:/ / www.sikhcoalition.org/blog/2014/avaaz-interfaith-greeting-qconnecting-with-1984q-smallgrants-pool-anti-bullying-congress-letter-and-more/ (accessed on 20 January 2021).

Sikh Coalition. 2019. Hate Crime Tracking and Intervention. Available online: https://www.sikhcoalition.org/our-work/preventinghate-and-discrimination/hate-crime-tracking-and-prevention/ (accessed on 20 January 2021).

Sikh Family Center. 2020. Available online: https:/ / sikhfamilycenter.org/ (accessed on 21 December 2020).

Singh, Inder Jit. 2003. Being and Becoming a Sikh. Ontario: The Centennial Foundation.

Singh, Jaideep. 2008. Diasporic Community Building Enterprise: Race, Religion and Sikh American Grassroots Political Organizing Before 9/11. Berkeley: University of California, UMI.

Singh, Jaideep. 2013. Memory, Invisibility, and the Oak Creek Gurdwara Massacre. Sikh Formations: Religion, Culture, Theory. [CrossRef]

Singh, Nikky-Guninder Kaur. 2016. Babarvani and the call for gender justice. Sikh Formations: Religion, Culture, Theory. [CrossRef]

Singh, Pashaura. 2020. “Speaking Truth to Power: Exploring Guru Nanak's Babu-rvani in Light of the Babunama. Religions 11: 328. [CrossRef]

Verma, Rita. 2008. Backlash: South Asian Immigrant Voices on the Margins. Rotterdam: Sense Publishers.

Wallace, Anthony F. C. 1956. Revitalization Movements. American Anthropologist 58: 264-81. [CrossRef]

Yaccino, Steven, Michael Schwirtz, and Marc Santora. 2012. Gunman Kills 6 at a Sikh Temple near Milwaukee. Available online: https:/ / www.nytimes.com/2012/08/06/us/shooting-reported-at-temple-in-wisconsin.html (accessed on 22 January 2021). 